\title{
Treatment of maxillary osteomyelitis after facial trauma
}

\author{
Tratamento da osteomielite maxilar após trauma facial \\ Tratamiento de la osteomielitis maxilar después de trauma facial \\ José Carlos Garcia de MENDONÇA ${ }^{1}$ \\ Fabio Nakao ARASHIRO ${ }^{2}$ \\ Maísa de Oliveira AGUILLERA ${ }^{3}$ \\ Muryllo Eduardo Sales dos SANTOS ${ }^{4}$ \\ Gustavo Silva PELISSARO 5 \\ Ellen Cristina GAETTI JARDIM ${ }^{6}$ \\ ${ }^{1} D D S, M S c, P h D$, Professor, Department of Oral and Maxillofacial Surgery, Federal University of Mato Grosso do Sul (UFMS), \\ 79070-900 Campo Grande - MS, Brazil \\ ${ }^{2} D D S, M S c, P h D$, Professor, Department of Endodontics, Federal University of Mato Grosso do Sul (UFMS), \\ 79070-900 Campo Grande - MS, Brazil \\ ${ }^{3} D D S$, Resident in Oral and Maxillofacial Surgery, Maria Aparecida Pedrossian Hospital, Federal University of Mato Grosso do Sul (UFMS), \\ 79070-900 Campo Grande - MS, Brazil \\ ${ }^{4} D D S$, Resident in Oral and Maxillofacial Surgery, Maria Aparecida Pedrossian Hospital, Federal University of Mato Grosso do Sul (UFMS), \\ 79070-900 Campo Grande - MS, Brazil \\ ${ }^{5}$ DDS, MSc, Oral and Maxillofacial Surgeon, Maria Aparecida Pedrossian Hospital, Federal University of Mato Grosso do Sul (UFMS), \\ 79070-900 Campo Grande-MS, Brazil \\ ${ }^{6}$ DDS, MSc, PhD, Professor, Department of Oral and Maxillofacial Surgery, Federal University of Mato Grosso do Sul (UFMS), \\ 79070-900 Campo Grande - MS, Brazil
}

\begin{abstract}
Osteomyelitis is an inflammatory condition in the medullary spaces or the cortical surface of bones. It can be acute or chronic and extend beyond the original site. Also, it can be caused by several factors, among them as a result of untreated dental trauma. Correct diagnosis and individualized treatment are essential for success. The aim is to report a case of chronic osteomyelitis due to a history of dental trauma in the anterior region of the maxilla in a 21 -years-old patient without associated comorbidities, focusing on the success of the therapy employed. It is known that the treatment of osteomyelitis is still a challenge because of the microbiota present. The treatment recommended with higher success rates is the removal of bone sequestration associated with antibiotic therapy, which has shown satisfactory results and maintenance of the dental elements in function.

Descriptors: Osteomyelitis; Tooth Injuries; Maxilla.

Resumo

A osteomielite é uma condição inflamatória nos espaços medulares ou na superfície cortical dos ossos. Pode ser agudo ou crônico e se estender além do local original. Além disso, pode ser causado por vários fatores, entre eles, o resultado de um traumatismo dentário não tratado. O diagnóstico correto e o tratamento individualizado são essenciais para o sucesso. 0 objetivo é relatar um caso de osteomielite crônica por história de traumatismo dentário na região anterior da maxila em paciente de 21 anos sem comorbidades associadas, enfocando o sucesso da terapia empregada. Sabe-se que o tratamento da osteomielite ainda é um desafio devido à microbiota presente. O tratamento recomendado com maiores taxas de sucesso é a remoção do sequestro ósseo associado à antibioticoterapia, que tem mostrado resultados satisfatórios e manutenção dos elementos dentários em função.

Descritores: Osteomielite; Traumatismos Dentários; Maxila.

\section{Resumen}

La osteomielitis es una afección inflamatoria en los espacios medulares o la superficie cortical de los huesos. Puede ser aguda o crónica y extenderse más allá del sitio original. Además, puede deberse a varios factores, entre ellos el resultado de un traumatismo dental no tratado. El diagnóstico correcto y el tratamiento individualizado son fundamentales para el éxito. El objetivo es reportar un caso de osteomielitis crónica por antecedente de traumatismo dentario en la región anterior del maxilar en un paciente de 21 años sin comorbilidades asociadas, centrándose en el éxito de la terapia empleada. Se sabe que el tratamiento de la osteomielitis sigue siendo un desafío debido a la microbiota presente. El tratamiento recomendado con mayores tasas de éxito es la eliminación del secuestro óseo asociado a la terapia antibiótica, que ha mostrado resultados satisfactorios y mantenimiento de los elementos dentales en función.
\end{abstract}

Descriptores: Osteomielitis; Traumatismos de los Dientes; Maxilar.

INTRODUCTION

Osteomyelitis is an inflammatory condition affecting the medullary spaces or cortical bone surface caused by bacterial infections, leading to widespread lytic destruction, suppuration, and sequestration of the involved bone ${ }^{1}$. Osteomyelitis of the maxilla is rare. It can be caused by facial trauma affecting tooth structures or causing fractures of the alveolar bone ${ }^{2}$. Radiographically this chronic process can be seen as areas of local radiolucency with uniform or speckled patterns besides areas of bone sequestration ${ }^{3}$.

Commonly for treatment of osteomyelitis, debridement of necrotic bone and extraction of dental elements is necessary. Hence, osteomyelitis of the anterior maxilla is a significant challenge for the patient's subsequent oral rehabilitation, considering it is a region of lower bone density, even more, when it is affected by an infectious condition, leading to a very evident tissue loss ${ }^{1}$.

Thus, the objective is to present the clinical management of maxillary osteomyelitis after facial trauma with the maintenance of the traumatized dental elements.

CLINICAL CASE

A 21-year-old patient was referred with a history of anterior maxillary cyst without regression after endodontic treatment of the upper right lateral incisor and purulent exudate in nasal and gingival regions for six months. During anamnesis, the patient reported a 
skateboard fall that resulted in a painful growth in the palate, causing mobility of the anterior upper teeth, unpleasant taste, and odor in the mouth. Clinical examination showed the mobility of the upper central incisors. Local erythema and significant mobility on palpation were observed in the fornix region above the upper right incisor. CT scan showed extensive bone loss associated with a hypodense lesion above the upper right central and lateral incisors, with rupture of the buccal and palatal bone cortices (Figure 1).
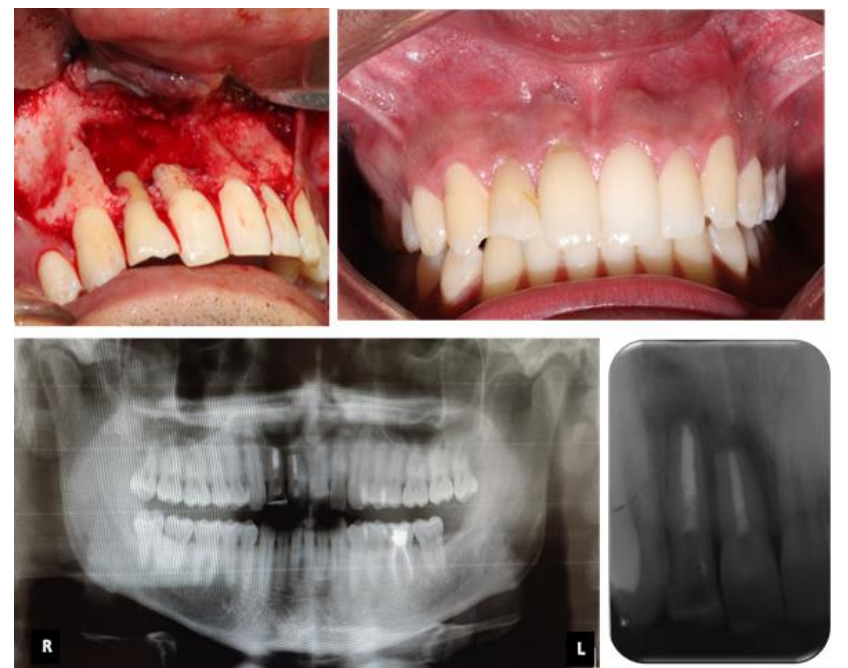

Figure 1: Initial aspect showing limits of the injury and destruction of the bucco-lingual cortical bone.

A surgical procedure was performed after root canal instrumentation, followed by obturation of the upper right central incisor and conservative treatment of the upper left central incisor. General anesthesia was used with nasotracheal intubation. Novak-Peter incision was made from the upper right canine to the upper left lateral one. After exposure of the anterior region of the maxilla to the anterior nasal spine, it was observed that the buccal cortical bone above the upper right central and lateral incisors was destructed, with the presence of darkened granulation tissue associated with purulent exudate, necrotic bone, and absence of capsule. Curettage of the lesion and removal of necrotic bone tissue with bone regularisation were performed, followed by apicoectomy of the upper right central and lateral incisors, cavity cleaning with abundant irrigation with $0.9 \%$ saline solution and $5-0$ nylon suture. An Erich arch bar was attached to the anterior upper teeth (canine to canine). Bone fragment and soft tissue inside the lesion were sent for histopathological analysis, which revealed inflammatory infiltrate, ulceration and associated necrosis, indicating presence of periapical cyst with signs of chronic osteomyelitis.

The presence of an infected cyst of traumatic origin, which had been inadequately treated for a relatively long time, caused a severe late complication, that is, osteomyelitis. This situation was evidenced by tomographic examination, showing a hypodense lesion in the anterior maxilla, cortical bone rupture, and unsuccessful endodontic treatment of the upper right lateral incisor. In the 4-month follow up, new bone formation was observed with no dental mobility (Figure 2).

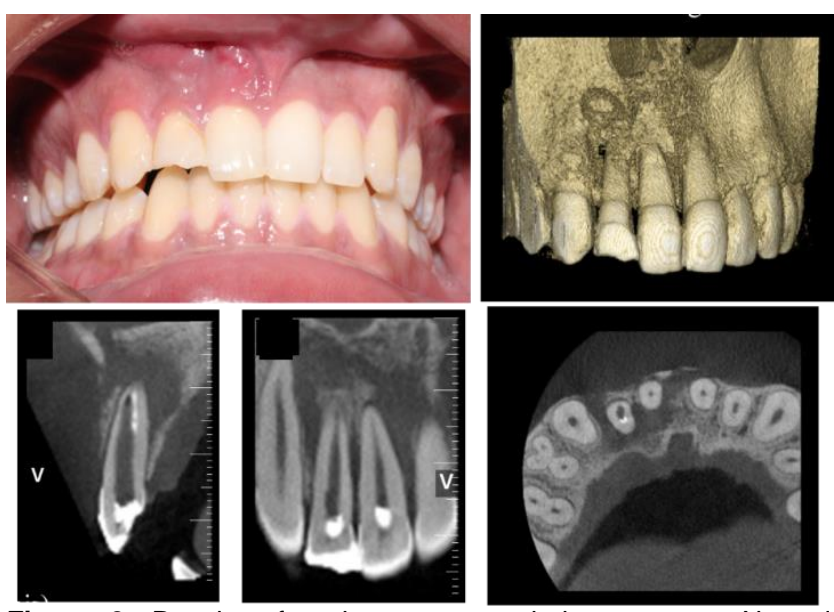

Figure 2: Results after the recommended treatments. Norma clinical aspect and bone neo-formation.

DISCUSSION

The treatment of osteomyelitis is a significant challenge for the oral and maxillofacial surgeon. It is based on the elimination of the infectious focus as soon as possible associated with broad-spectrum antibiotic therapy and the removal of significant bone sequestrations due to less vascularization. This bone sequestration commonly, in the toothed area, generates extraction of the involved teeth besides functional and aesthetic damage when in the anterior region of the jaws.

In many cases, the bone loss would be indicative of condemnation of the dental element and its extraction ${ }^{4}$. In this case, endodontic treatment associated with surgical intervention, removal of the necrotic bone tissue (as a result of the lytic destruction), placement of an Erich arch bar and antibiotic therapy were shown to be effective in the maintenance of the patient's teeth both functionally and aesthetically.

Chronic osteomyelitis is a complex and long-lasting infection with an insidious course, which can be unpredictable ${ }^{5-7}$. The elimination of the infectious focus and maintenance of the dental elements even in conditions of considerable bone loss followed by new bone formation indicates the conservative technique used as a great success.

The minimally invasive periodontal surgical technique associated with endodontics and the periodic observations of the case have 
so far shown no symptoms that indicate recurrence of the infectious condition. This result becomes more evident when the thin bone tissue characteristic of the maxilla's anterior region becomes noticeable.

\section{CONCLUSION}

The curettage of bone tissue with the removal of the dental infectious focus through root canal treatment, and the maintenance of primary stability with the use of the Erich Arch Bar were sufficient for the long-term functional and aesthetic maintenance of the patient's teeth, demonstrating the success of the technique used.

\section{ACKNOWLEDGMENT}

This study was partially financed by the Coordination for the Improvement of Higher Education Personnel - Brazil (CAPES).

\section{REFERENCES}

1. Mehra H, Gupta S, Gupta H, Sinha V, Singh J. Chronic suppurative osteomyelitis of mandible: a case report. Craniomaxillofac Trauma Reconstr. 2013;6(3):197-200.

2. Gill GS, Pulcini M. Maxillary Osteomyelitis in a Patient with Pansinusitis and Recently Diagnosed Focal Segmental Glomerulosclerosis. Cureus. 2019;11(8):e5347.

3. Mardini S, Gohel A. Imaging of Odontogenic Infections. Radiol Clin North Am. 2018;56(1):31-44.

4. Andre CV, Khonsari RH, Ernenwein D, Goudot $P$, Ruhin B. Osteomyelitis of the jaws: A retrospective series of 40 patients. J Stomatol Oral Maxillofac Surg. 2017;118(5):261-64

5. Gaetti-Jardim Júnior E, Fardin AC, GaettiJardim EC, de Castro AL, Schweitzer CM, Avila-Campos MJ. Microbiota associated with chronic osteomyelitis of the jaws. Braz $\mathrm{J}$ Microbiol. 2010;41(4):1056-64.

6. Masocatto DC, Oliveira MM, Mendonça JCG. Osteomielite crônica mandibular: relato de caso. Arch Health Invest. 2017;6(2):48-52

7. Aguillera MO, Garcia de Mendonça JC, Gomes Paiva Oliveira J, Gaetti Jardim EC, Silva Pelissaro G, Gavioli Meira Santos AO, Campidelli Oliveira B. Osteomielite de mandíbula e fratura patológica: tratamento de sequela operatória. Arch Health Invest. 2018;7 (Spec Iss 3):330.

\section{CONFLICTS OF INTERESTS}

The authors declare no conflicts of interests.

\section{CORRESPONDING AUTHOR}

\section{Ellen Cristina Gaetti Jardim}

Universidade Federal de Mato Grosso do Sul

Campo Grande - Cidade Universitária

Zip code: $79070-900$

(+55 67) 3345-7682

E-mail: ellen.jardim@ufms.br
Received 19/08/2020

Accepted 23/10/2020 